Another addition to the structure of this interesting Palæozoic Echinus, made by Mr. Baily, was the discovery of spines which he had observed on a specimen of the same species, also from Hook Point, in the Collection of the Geological Survey of Ireland, a number of the minute spines still remaining attached to the plates, the principal tubercles on which are perforated, and surrounded by a circle of smaller ones. These spines were less than a tenth of an inch in length, and, on examination with a microscope, were found to be longitudinally striated.

On the Signtficance of the Sequence of Rocks and Fossils. By Harry SEELEY, F.G.S.

TAVING assumed as axioms, that clays are the mud of rivers, that sandstones are the detritus of old crystalline rocks, while limestones were organically or chemically formed, the author contrasted the Cretaceous and Jurassic Rocks, and the sequence of the beds forming them; and, from the alternations of the strata, he deduced the alternations of the upheaval of continents and the nature of the rocks presented for denudation. He then, by way of illustration, worked out the physical geography of the Cretaceous period, as evidenced by the rocks of the Eastern and Northern Counties; and, having considered the effect of these physical revolutions upon the fauna of the ocean-floor, it was concluded that the operation of elevation and depression, in the ways pointed out, might produce all the phenomena of existing life-provinces on land and by sea, and similar life-provinces in the seas of past time. It was then shown that breaks between strata do not generally indicate denudation or breaks in time, but merely upheaval or depression of old lands, bringing into wear new rock-material, and causing the immigration of a new province of marine life. Mr. Seeley then showed that life was no measure of time; and concluded by controverting the teaching of Lyell, Forbes, Haughton, Hennessey, \&c., that fossil species are any evidence of change of climate. He showed that one existing species could not tell anything about the climatal conditions of another, and therefore that the climate of extinct genera and families could not be inferred from existing analogues. The old faunæ were not universal; nor could the existing analogues bave reached their present homes without wandering through very different climates. Evidence was adduced of extensive migrations, and it was concluded that in old times the species migrated, not the climate.

\title{
OORRESPONDEINCE.
}

\section{To the Editors of the Geological Magazine.}

I THIN that it might be of service to those who, like myself, live in the neighbourhood of deposits containing the remains of Elephants and other large Mammalia, if you would describe the method that was used to extract the tusks of the Ilford specimen of Elephas primigenius from the matrix. I have sec $n$ many tusks ruined ly unskiliul 
attempts to remove them: and I feel sure that more than ordinary skill must have been employed to obtain the specimens in question in such excellent condition.-I am, \&c. O. Fisher.

Flumstead, Colchester : Dec. 12, 1864.

To the Editors of the Geological Magazine.

BEING engaged as Resident Engineer superintending the construction of the submarine foundations for the sea-forts near ב=-二 $=$ High-water Spithead, now in course of erection

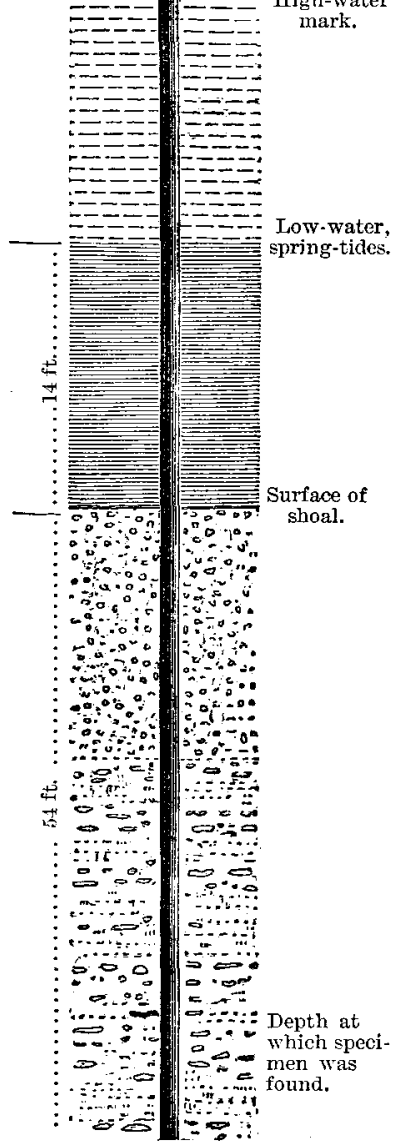

Extreme depth to which cylinder is sunk. under the immediate direction of $\mathrm{Mr}$. Hawkshaw, I send you a fossil lower jaw-bone of some Ruminant, discovered, in August last, in a deposit of flinty gravel and shingle (stained with oxide of iron) at No Man's Land Shoal,' si tuate about $1 \frac{3}{4}$ mile NE. of Nettlestone Point, eastward of Ryde, Isle of Wight. Large flat pebbles from the limestone of the Isle of Wight are distributed through the entire mass of flinty shingle gravel and sand forming the shoal. The iron cylinder has been sunk into this shingle bed to a depth of 54 feet without penetrating it. The jaw-bone was met with at a depth of 40 feet beneath the surface of the shoal, whilst sinking the cylinder. The following sketch represents a section of the shoal, and shows the depth at which the specimen was found. Probably in times not far remote the Isle of Wight formed part of the mainland, and the Solent was an extensive estuary, of which Poole Harbour may have been the head.*_-Yours truly,

Thomas Harris.

108 High Street, Portsarouth.

We append a note from $M r$. W. Davies.-ED.

The specimen Mr. Harris refers to in his letter has been presented by him to the British Museum. It is the left ramus of the lower jaw of the Red-deer (Cervus elaphus, Linn.), having 5 teeth in sitû, the crowns of which are well worn, proving it to have belonged to an adult and rather aged individual. On the inner side of the teeth and jaw are patches of a thin incrustation of iron-pyrites (which at first sight appear like a growth of lichens). The bone is remarkably fresh-looking, retaining most of

* See 'Geologist,' vol. v., p. 453. 